\title{
ANALYSIS OF LINGUISTIC FEATURES IN THE FRENCH TRANSLATION OF OSOFISAN'S ONCE UPON FOUR ROBBERS
}

As long as there are literary works then linguistic features will always be pertinent in communication, which is also applicable to translation studies. A language is like an umbilical cord that is inseparable in communication, either in an oral or written form. The use of language in this paper is very unique, as both the source and the target texts depict the linguistic background of the focal playwright. As with other writers, Femi Osofisan, a Yoruba man in Nigeria, exhibits his cultural background in the presentation of the text Once Upon Four Robbers. The playwright makes use of Yoruba songs, incantations, Ifá ${ }^{1}$ panegyrics, Yoruba dirges and other Yoruba cultural items in developing the intrigue of his play. This is also reflected in the playwright's choice of words and the presentation of his messages to the audience. It is clear that while two languages can have identical linguistic features, they cannot have wholly the same linguistic elements. Both English and French languages rarely have the same structural features at the linguistic level, and this is reflected in our study. The deep review of the text in this study convinces us that there are a lot of obstacles associated with the translation of plays, especially when such plays contain some elements of indigenous languages, folk songs, jokes, incantations, Ifá chants, mimes and other indigenous thoughts. The translation of indigenous thoughts from indigenous languages into European one is often full of tasks that need cross-cultural knowledge as a result of cultural variations. In this study, the approaches employed are descriptive and comparative. The data is chosen from the texts and analyses are made by comparing the linguistic features from the source and target texts, and this is based on the interpretative theory of translation. The examples presented in this study are directly from the text and its translated version. 


\section{TRANSLATING DRAMA TEXTS}

The mission of a translator of a dramatic work is slightly different from that of other literary genres because it involves performance. A drama text is written in order to be performed on stage. Drama translation is also impossible without relating it to the sociocultural context in which it was conceived. Drama texts cannot be translated like other genres of literature, such as prose and poetry, and the three major genres of literature cannot be read in the same manner. Some parts of a play may create an unending suspense which, if a translator is not conversant with this, they may not be able to translate or support the message of the source text in the target text. Drama texts are full of dialogues, rhythms, intonations, patterns, pitches, changes in volume and other dramatic elements. Linguistic expressions in most drama texts are symbols or signs constituted not only as discourse signs, but also as other signs. According to Komissarov (1991: 5)

In translating a play, the translator must bear in mind the requirements of theatrical presentation of such play; at all times, the translator must hear the voice that speaks and take into consideration the 'gesture' of the language, all rhythms and pauses that occur when the written text is spoken.

This shows that drama as a genre of literature is very different from other genres because it involves actions. The translator of a drama text must put such actions in their mind in order not to miss out the aesthetics and embellishments of the source text in the target text. The experience of Samuel Beckett, playwright and self-translator, shows the tremendous influence of self-translation on the message of the translator's original text. Beckett's En attendant Godot is translated by the playwright as Waiting for Godot, which makes clearer certain aspects of his mindset in the translated version. In Holmes' view (1970:79), the points of difference between the author of the original and the translator are perhaps another way of viewing equivalence as an objective criterion of translation quality:

The differences between the author and the translator are governed by the differing social and literary situations. The conventional designation of which is the taste of the day. In practice, these differences between the original and the translation can be reduced to shifts in the structural process. Each individual method of translation is determined by the presence or absence of shifts in the various layers of the translation. All that appears as new with respect to the original, or fails to appear where it might have been expected, may be interpreted as a shift. The fact that the process of translation involves shifts in the semantic properties of the text does not mean that the translator wishes to underemphasise the semantic appeal of the original. The very opposite is true. 
From Holmes's analogy about translation it can be deduced that it involves shifts that are cultural or linguistic in the structural process. He also emphasises the relevance of method and style of translation in order to achieve the semantic appeal of the original.

\subsection{Problems Relating to the Translation of Drama Texts}

Many translation scholars have made different assertions as regard the problems facing the translations of drama texts. It is noted that every genre of literature poses some specific problems of translating into a particular language, and drama translation is no exception. The fundamental fact about the problems of translating drama texts, or plays, is that the tasks are related to cultural, linguistic and performative issues. Many literary translations fail to achieve the fame and quality of the original texts as a result of factors relating to this reality. Some of the impediments are based on the cognitive, stylistic, ethical or cultural and performance strictures. Most translators translate word-for-word without considering the integral unit and translating in sections. Moreover, some drama texts are not translated intention by intention, and thus elements of pragmatics and discourse prosody in translation are not taken into consideration. Another problem is related to the author's style, in which may not be comprehended by the translator. An individual writer has their own her style of writing, and a translator should not insist on the style of the source text but instead the focus should be how the source message could be passed to the target audience. Furthermore, the style that is incorporated in a translation can aid the better comprehension of the audience.

There is also a problem of false friends (faux-amis), which is rampant in general translation. Moreover, in plays proper names are normally changed to suit the graphic and phonic instances of the source text, but very often this brings about contradictions. There is also a problem of the mistranslation of information, sub-interpretation of the original text and as well superficial interpretation of connections between intentional correlatives. Drama texts cannot be translated in the same way as prose, because they involve action and performance. According to Steiner (1975:396):

A bad translation is one which is inadequate to its source-text for reasons which can be legion and obvious. The translator has misconstrued the original through ignorance, haste, or personal limitation. He lacks the mastery of his own language required for adequate representation. He has made a stylistic or psychological blunder in choosing his text; his own sensibility and that of the author whom he is translating are discordant. Where there is difficulty, the bad translator elides or paraphrases. Where there is elevation he inflates and where author offends he smoothes. 
Steiner's point here is that a bad translation moves far from the concept of the source text as a result of misconception or ignorance, haste or some other reasons that can arise in the work of a translator. For example, perhaps the translator lacks knowledge of the languages involved. Kolawole and Moruwawon (2007: 375-379) state that "the translator had the responsibility of finding a solution to the most daunting problems, and he declared that the functional view must be adopted with regard not only to meaning but also to style and form". This reiterates the relevance of style and form in translation, and Kolawole and Moruwawon say that the solution to the most daunting problems of translation is to adopt not only the meaning of the original but also its stylistic preoccupation. The word 'meaning' has different implications, and these can be polysemous or ambiguous in nature. Therefore, a translator is expected to put into consideration aspects of cognitive premises, psychology and sociolinguistics in their work, and above all the appropriate choice of words is necessary.

Another problem associated with the translation of drama texts is an indirect use of language (figurative expressions). The aesthetic use of figurative expressions in literature and most especially in plays can result to over- or under-translation of the source message into the target language. Furthermore, it is as well noted that the methodology used in translating prose is sometimes also inappropriately used to translate drama texts. Furthermore, Nord (1991) categorises the problems of translating drama into different phases - as pragmatic problems which refer to the fact that there may be difference between the situations in the source and target cultures. These differences include time, place, and so on, and in order to identify potential pragmatic problems we need to check the extra textual factors for each text. He further states that there are a number of linguistic problems, as most scholars emphasise. These arise as a result of differences in the structure, vocabulary and syntax of the source and target languages. Along with the other problems of translating drama are those related to cultural issues. According to Nord, cultural problems are the result of the differences in norms and conventions that guide verbal and non-verbal behaviours in the two cultures involved, as every culture has its own habits and conventions. He also notes that there are text-specific problems, which depend on the type and nature of the texts involved in translation. This means that problems may arise as a result of the complexity of the material in a particular text. This can be in the form of the choice of words, use of figures of speech, choice of proverbs, and so on. Moreover, most of the problems mentioned in this section are reflected in the current study, with quite a few issues raised with regard to untranslatability, culture-based problems, style and semantics, and by extension discourse prosody.

\subsection{Interpretative Theory of Translation}

The interpretative theory of translation is interdisciplinary in nature, because it is adopted in translation studies, sociology, applied linguistics, psychology and many other fields of studies. The theory was developed by two translation scholars in the 1970s, with Seleskovich and Lederer (2001) challenging the view prevailing at that time that: 
Translation was no more than a linguistic activity, one language being merely transcended into another. She believes translation is a triangular process- from language to sense and from sense to the other language. The Interpretative Theory of Translation was coined before translation studies became a field of study.

Seleskovich and Lederer see translation as a triangular process - from language to sense and from sense to the other language. In connection with the theory, the process of translation is divided into three phases: comprehension, deverbalisation and reformulation or re-expression. According to Selescovitch and Lederer (1983):

The component comprehension means adding extra linguistic knowledge to linguistic signs, new information constantly enriching extra-linguistic knowledge.

There is another important element in the interpretative theory according to Selescovitch (1983):

The process of translation is the "deverbalisation" to comprehension and reformulation. Everybody deverbalises in one way or the other. For instance, we do keep in mind facts, notions, concepts and events conveyed by words, but we do not retain the words in our memory. Languages and thoughts are located in different areas of the brain. The concept of deverbalisation in Interpretation Translation Theory is common in oral speech and interpretation; it is more difficult to observe in written translation. Deverbalisation needs an extra effort by translators to implement. In the stage of deverbalisation, sense is freed from all linguistic structures of the source language.

The next stage is the reformation of meaning according to the two theorists. In this stage, a translator re-expresses the message of the source text into the target message. In this case, meanings are expected to be more important than words. In the interpretative theory of translation, the translation of a text should produce the same cognitive, affective and aesthetic effects on readers as the original text does through comprehension, deverbalisation and reformulation. Selescovitch and Lederer (1983) support the idea by remarking that:

Croire qu'interpréter consiste à passer directement d'une langue à l'autre postule des savoirs, dire qu'interpréter consiste à passer par le sens postule en outre de l'intelligence.

To believe that to interpret is to pass directly from one language to another and this postulates knowledge, to say that interpreting is to go through the meaning to postulate in addition to intelligence. (Our translation) 
This shows that meaning takes prominence in the act of translating and interpreting, with knowledge of the source and target languages having a very important position. ANALYSIS OF LINGUISTIC FEATURES IN THE FRENCH
TRANSLATION OF OSOFISAN'S ONCE UPON FOUR ROBBERS

\subsection{Translating Once Upon Four Robbers as II était une fois quatre voleurs}

The first linguistic feature to be considered in Osofisan's play is the presentation of the title and how it is translated into French. Since translation can be done in numerous ways to suit the original message in the target text, as suggested by the interpretative theory, the issue of sense for sense translation is pertinent here. A title of this nature can be translated into different forms without losing the original message of the source text, and this all depends on the discretion of the translator. Considering Osofisan's title from the literal point of view, one would have thought that the translator should have presented as Quatre voleurs, or Une fois quatre voleurs or Il y avait quatre voleurs. The title in the source text is idiomatic, and Nicole Medjigbodo approaches its translation in an idiomatic manner. She was able to find the cultural and linguistic equivalence of the title in the French milieu. The translator would also have thought of other alternatives if she could not find the cultural and linguistic equivalent of the title in French, and other options could be Quand jadis, quatre voleurs or Autrefois, quatre voleurs. In essence, the translator approached the French translation of the title by trying to find the direct equivalent to the expression. The expression Once upon a time is common among Africans, most especially at when elders narrate a story or tell a tale under the moonlight. Nicole Medjigbodo thus presents her French title to be able to depict the semantic content of the source text in the target text.

\subsection{French translation of pidgin and other expressions}

Indigenous languages or dialects can be in the form of vernaculars, which include from dialects, slang, street languages, argots, pidgin, lingo, jargon, idioms, patois, idiolects, and so on. A vernacular can be any language spoken or written outside the official language of the linguistic community. In Osofisan's literary opus, there are numerous local languages. Despite the deliberate use of poor English by the playwright to create humour and satire and to depict the class level of the speakers, Nicole Medjigbodo was able to translate the words, phrases and sentences according to the intention of the playwright. For instance:

Yess aaah. ou .......!

Darring mi! $!^{2}$ ma chéééérie!

2 Darring mi! It means "my dear" 
Yes, di yah! I' am here!

How many pickin we get? ${ }^{3}$ On a combien de gosses?

Pardon? Quoi?

Shirrup! La ferme

Pitakwa $^{4}$ Local name for Port-Harcourt (p.57)

In the above examples, we can observe that there are certain vernacular expressions or items of slang employed by the playwright. According to the interpretative theory of translation, the translator re-expresses or reformulates the jargons and pidgin of the source message. Seleskovitch and Lederer emphasise that the rendering of the message of the source text may not necessarily take the same linguistic pattern as the original message. The source message must be reformulated to the target message in a language that the target audience can fully understand. In the context of the current study, Medjigbodo attempts to find the equivalents of the local pidgins so as to produce the messages of the source text in the target text. She translates the vernacular expressions by replacing those vernaculars in English with others French, which is the target language. It is certain that she must have made some effort to be able to find the equivalents of the above expressions, since they are not standard French like the other elements represented in this study. From the above expressions, we can deduce that Osofisan employs the vernacular to create some dramatic effects, such as satire and humour; likewise, Medjigbodo's French translation of the expressions is done with the use of pidgin French. For example, the expression "Darring mi!" is translated as "Ma chéeeerie!" From this expression, we can observe that the translator does the French translation according to the message from the source text.

\subsection{Translation of Koranic Verses}

In the source text of our study, the use of Koranic chants is common from the prologue of the work to the epilogue. This is because this literary work involves the activities of a Muslim cleric, Aafa. Equally, as part of the intrigue of the play there is the use of a mixed religion, with elements of Islam and traditional religions. To reinforce this idea of syncretism, in the play Aafa, a Muslim cleric, brings out the paraphernalia of Ifá and that of Islamic chants.

In the view of Hatim and Munday (2004:15):

The notion of untranslatability is described as a relative notion, and it has to do with extent to which, despite obvious differences in linguistic structure (grammar, vocabulary, etc), meaning can still be adequately expressed across languages. But, for this to be possible, meaning has to be understood not only in

3 How many pickin we get? This means how many children do they have?

4 Pitakwa. This concentrates on the accentuation of Port-Harcort. 
terms of what the source text (ST) contains, but also equally significantly, in terms of such factors as communicative purpose of translation.

In our study, our selected text has various kinds of aesthetic functions which mean the issue of untranslatability is a common one. For instance, in Once Upon Four Robbers Osofisan makes use of some well-known Islamic chants, likewise, Medjigbodo uses the same chants and expressions directly without translating them.

i. Aafa: il étend la natte tout en chantant:

Ataiyatu : lilahi ${ }^{5}$

Azakiyatu: lilahi

Ike oluwa: ${ }^{6}$ lilahi

Ige oluwa: ${ }^{7}$ lilahi,

Ko lo ba Mohamadu - Lilahi

Ataiyatu Salamatu ! Etc. (p.16)

ii. Aafa : Wahalu hairu hafizan, wauma arihamu rohimim. (p.17)

From the above example, it can be deduced that the translation of Islamic chants cannot be easy, except when such chants are subjected to transliteration, and in this way translators can translate the chants into other indigenous and foreign languages. The idea is applicable to our text, Once Upon Four Robbers, where the playwright translates his songs in Yoruba language into English so as to make the translation easy for non-Yoruba translators and to have a wider audience.

\subsection{Translation of Proper Nouns}

A noun that is designated to a particular being or thing, does not take a limiting modifier, and is usually capitalised, is called a proper noun. It is obvious from our study that Osofisan makes use of different proper nouns such as the names of deities, kings, places and so on. For instance :

\section{Medjigbodo's Translation}

$<$ Fils d'Enire, fils d'Enírè ${ }^{8}$

De ceux qui frappent vite et fort

\footnotetext{
5 Ataiyatu : lilahi. Islamic chant

6 Iké olúwa: Honouring Mohammed

7 İgè olúwa. Honouring Mohammed

8 Enire. A Yoruba tribe in Nigeria
} 
Ifá, nous t'invitons sous notre toît!

Ewì d'Adó ${ }^{9}$

Onsa de Détà ${ }^{10}$

Erinmi d'Òwò ${ }^{11}$

Ifá, nous t'appelons ici!

Gbòlàgoko, ${ }^{12}$ qui assoit la richesse, etc. (p.28)

From the above Ifá panegyrics, we observe that it is very hard to find the cultural and linguistic equivalents of African proper nouns in European languages. It can thus be seen that some special proper nouns remain as used in the source text so as to avoid translation loss in the target language. These words are as follows: Eníre, Ewì, Adó, Onsa, Détà, Erinmi, Òwò, Ifá and Gbólágoko. Another example of proper nouns in the translation is shown below:

\section{Medjigbodo's Translation:}

L'homme s'approchera de moi et nous allons partager ensemble, une fois de plus, la pomme d'Obatala. Il va me séduire des mêmes mensonges, me pénétrer dans un moment d'abandon et, au cours du neuvième mois, mes batards vont se déverser de nouveau comme de la merde. Oduduwa sera là tout prêt à prendre soin d'eux, à leur donner une forme. La merde va respirer l'air s'abreuver à la fraîcheur de la pluie et Edumare va leur apprendre comment se servir de leurs pieds. Ogun dans une gourde attend être découvert. Et ils vont boire, mes enfants, le soleil sera dans leurs yeux, le soleil et Eshu Laaroye, dans toutes les cellules de leur cerveau, et l'un va poignarder l'autre et laver sa chevelure dans son sang. Je vais crier, je vais appeler mon époux, mais Orunmila. Etc. (p.7)

In the example cited above, Nicole Medjigbodo makes use of Yoruba proper nouns such as: Obàtálá, ${ }^{13}$ Odùduwà, ${ }^{14}$ Ėdùmàrè, ${ }^{15}$ Ògún, ${ }^{16}$ Èshùn Láaróyè ${ }^{17}$ and Òrúnmìlà. ${ }^{18}$ These are the names of deities in Yoruba lands, and since the text is translated into another language the cultural divergence is reflected in the target language and thereby the issue of untranslatability sets in. It is better the way Nicole Medjigbodo attempts her

\footnotetext{
9 Ewì d'Adó. This is Ado king's title, an ancient city in Nigeria.

10 Onsa de Deta. A deity in Delta state of Nigeria.

11 Erinmi d'Òwò. A deity in Òwò, a city in Ondo state of Nigeria.

12 Gbólágoko. This means blessed with wealth.

13 Obàtálá. A divinity in Yoruba lands

14 Odùduwà. A deity in Yoruba lands

15 Èdùmàrè. Supreme God in Yoruba language

16 Ogun. This a god of iron

17 Èshùn Láaróyè. One of the gods in Yoruba lands

18 Òrúnmilà. A divinity
} 
French translation, where most often for the names of the deities she makes use of footnotes, glossary and other illustrative devices for comprehension.

\subsection{Code-mixed Sentences and their Translations}

One of the linguistic features in the play is code-mixed sentences. In studies of African literature it is often observed that some writers cannot do without the use of code-mixed sentences, because they rely so much on their dialects and colloquial languages to depict their linguistic backgrounds. It is observed that the author often makes use of dialects to exhibit his socio-linguistic background, mingling these with English. For instance, songs, incantations, panegyrics, dirges, Ifá chants are written in Yoruba and self-translation was done by the playwright into English, with Nicole Medjigbodo translating the Yoruba folkloric elements into French, the target language. In essence, the major languages in our study are Yoruba, English and French, and code-mixed sentences are employed from the start to end of the play. In the translated version, the translator most often makes use of dialect, vernacular and Yoruba, whenever she cannot find a lexical equivalent of the linguistic items. As lexical words, phrases, clauses and sentences are code-mixed in the source text, so code-mixed sentences are also very common in the translated version. For instance, there is a combination of Yoruba and French in the translated text. Furthermore, we observe the use of Koranic chants in Arabic that are mixed with other languages. For instance:

i. Robi najini wahaali mimo yahamalum! ${ }^{19}$

ii. Walahu hairuhafizan, wauwa arihamu rohimim!

iii. Ataiyatu : lilahi

Azakiyatu : lilahi

Ike oluwa; lilahi

Ige oluwa: lilahi

Ko lo ba Mohamadu - Lilahi

Ataiyatu Salamatu! Etc. (Pp.16-17)

In the above extracts, Arabic is code-mixed with Yoruba, which means that the background of the playwright is reflected in his choice of language. The same idea can be seen in the translated work, as the translator makes use of code-mixed sentences to drive home the message of the source text into a target text. French is code-mixed with Yoruba and Arabic, as appropriate to the source text. Furthermore, there is also a mélange of musical solfa with French, which is the target language. In the French translation examined in this study, the translator employs musical notations as used in the source language, and these musical notations are the solfas relating to music and its components. For instance:

19 Robi najini wahaali mimo yahamalum. Islamic chants 
Corporal: "Do-re-mi", is it? I will $\underline{\text { do-re-mi }} \underline{20}$ you with bullets today! Robbers Soldier 1: Bu-u-u-ut, soja...... ${ }^{21}$

Corporal: Quite! You can't even sing a healthy, masculine song! "Do-re-mi”! Disgusting! Are you one of those wall geckos from England?

\section{Medjigbodo's Translation}

Le Caporal: Je t'ai eu, espèce de canaille!

Le Soldat: (Begayant de peur). Ch.......ch.......chef!

Le Caporal: Ferme-la! Tu ne peux même pas chanter un morceau énergique!

Do-re-mi-fa-sol! C'est une honte! Est-ce qu'on ne dirait pas un de ces grillons Européens!

"Do-re-mi-fa-sol" is a musical notation which is used by Osofisan, and in the translated version the tonic solfa is used in the same way as in the source text. In the play Once Upon Four Robbers, Osofisan makes of language as he likes. As observed in the French version of the play, the translator uses the playwright's language most often to avoid under- or over-translation of the source message.

\subsection{Translation of Figures of Speech}

A figure of speech is a word or phrase that has a meaning other than the literal one, and is also referred to as a literary device. It makes use of a comparison using verbal images to illustrate the speaker's intention, for effect, and to clarify the meaning via "rhetoric". Examples of such speech are similes, metaphors, oxymorons, and puns. In the play that is the focus of our study, the playwright makes use of diverse figures of speech, but the most common is the use of similes. A simile is an indirect comparison between two things or people which makes use of "as" and "like" to indicate the comparison. On the same note, the translator makes attempts to translate the similes in different forms to be able to maintain the naturalness of the messages of the source text in the target text, including in the following examples:

\section{Simile:}

i. Angola: like a ram. They slaughtered our leader like a Ramadan lamb. (p.22) Angola: Comme un bélier! Ils ont égorgé notre chef comme le bélier Sacrificiel. (p.6)

ii. Angola: And so you'll run, isn't it? Like a cheap half-kobo pick-pocket in the market pursed by women. (p.23)

20 Do-re-mi. Musical notation

21 Sójà. Yoruba accentuation from the English word "soldier" 
Angola: Et c'est pour ça que tu veux foutre le camp, hein? Comme un vulgaire voleur à la tire pourchassé par les femmes du marché. (p.9)

iii. You fed on worms and leftovers, your body nude like a carcass in the government mortuary, elbowing your way among other corpses. (p.24)

Tu t'es nourri de vers et déchets, nu comme un macchabée à la morgue, jouant des coudes au milieu d'autres cadavres. (p.10)

iv. Every time we went on a raid and had to kill, he broke down and sobbed like a silly school pickin. (p.24)

Chaque fois qu'on était sur un coup et il fallait descendre un type, il s'effondrait en pleurant comme un gosse stupide. (10)

v. Sarumi, the leader of the coast, who knew the creeks like the back of his palm. (p.26)

Sarumi, l'empereur de la côté, qui connaissant les criques comme la paume de sa main. (p.13)

vi. When he cunningly led officers on his trail to quick sand and watched them flounder like agbégijé. ${ }^{22}$ (p.26)

In essence, we can simply remark that the translation of a simile into any language is easily possible, because the idea is attached to two objects with which a comparison is made. The first example above compares "leader" with "Ramadan lamb" and it is translated without changing the structure of the source text, as "Ils ont égorgé notre chef comme le bélier sacrificiel'. The second example is far from a literal translation of the simile:

And so you'll run, isn't it? Like a cheap half-kobo pick-pocket in the market pursed by women. (p.23)

Et c'est pour ça que tu veux foutre le camp, hein? Comme un vulgaire voleur à la tire pourchassé par les femmes du marché.

In the above sentences, the translator translates the similes by following the structural pattern in English, making use of the words "as" or "like". Without the use of comparison words, a simile cannot effectively show its appeal as a rhetorical device. The same pattern of literal translation of is found in the third example, "You fed on worms and leftovers, your body nude like a carcass in the government mortuary, elbowing your way among other corpses" which is translated into French as "Tu t'es nourri de vers et déchets, nu comme un macchabée à la morgue, jouant des coudes au milieu d'autres cadavers."

The same pattern is observed in both the fourth and last examples presented above. Moreover, it is not necessary that similes be translated with the use of "like", "comme" in French, and it is also possible to use "rassembler" depending on the nature and type of simile. 


\section{Metaphor}

i. Hassan: The world is a market, we come to slaughter one another and sell the parts.... (p.72)

Hassan: Le monde est un marché, on y vient pour s'entre-égorger et pour vendre les morceaux. (p.78)

ii. Mama Alice: The market is our sanctuary. (p.72)

Mama Alice: Le marché est notre sanctuaire. (p.79)

A metaphor is a direct comparison between two objects or persons. While metaphors are hardly used in the play, the use of calque as a translation technique when dealing with them is common. In some texts, the translation of a metaphor can take another form rather than using the traditional approach to its translation. The above example "the market is our sanctuary "can also be translated as "le marché deviant notre sanctuaire". However, whatever method is used, the purpose of translation must be achieved by considering those using the target language.

\section{Onomatopoeia}

Onomatopoeia is another figures of speech, when a word sounds like what it is meant to represent.

"As lights slowly increase now with the growing day, a cock crows" (p.21)

"L'éclairage s'accentue avec la venue du jour, un coq chante"'(p.5)

The use of onomatopoeia is not common in the translated version of the play, as it is not in the source text. The example above shows that there is an equivalent of the expression "a cock crows" in French, which is the target language. The expression is translated as "un coq chante", as the sound of the expression gives its exact meaning in the source language, and is applicable in the target language. Therefore, in the translation of onomatopoeia, it is better to have the lexical equivalents of the expressions used in presenting the figure of speech. In this case, meanings are expected to be more important than words, as expressed by the interpretative theory of translation in the stage of reformation of meaning.

\section{4}

\section{CONCLUSION}

With reference to the objective and the theory adopted in this study, namely the interpretative theory of translation, it can be safely remarked that Nicole Medjigbodo tries to maintain the source message in her translation through comprehension, deverbalisation and reformation of content of the source text in the target text. However, on several occasions she makes use of direct translation techniques (calque, literal translation and loanwords) in conveying the message of the source text to the target text. This is as a 
result of the nature of the text, which contains the Yoruba culturally bound items. We can also conclude that, despite the fact that she is not originally from the milieu of the playwright, she is able to translate the Yoruba cultural items into French. Though the issue of untranslatability occurs in several places in the translated text, the socio-cultural importance of the translator's work is achieved by translating the minds of the entire audience. This means that the French audience is able to grasp the message of the play as it is, in the original text. Equally, it is observed that the original text is rich in Yoruba cultural features, as the playwright is a Yoruba man, and that the speech flow (intonation, accentuation and register) in the translated version is in line with the source text. This shows that the play can be performed in much the same way as the original, and allows the actors to give a plausible speech performance.

\section{BIBLIOGRAPHY}

HATIM, Basil/Jeremy MUNDAY (2004) Translation: An Advanced Resources Book. London/New York. Routledge.

HOLMES, James (1970) The Nature of Translation. Essays on the Theory and Practice of Literary Translation. L'Aja Brastislava.

KOLAWOLE, Samuel O./Samuel B. MORUWAWON (2007) Critical Approaches to the Notion of Translatability and Untranslatability of Texts in Translation Studies. Pakistan Journal of Social Sciences. 4(3), 375-379

KOMISSAROV, Vilen N. (1991) Language and Culture in Translation. Competitors or Collaborators? Traduction, Terminologie, Redaction, Vol 4, No 1, 5-10.

NIDA, Eugene A. (1964) Towards a Science of Translating, with Special Reference to Principles and Procedures involved in Bible Translating. Lerdes, Bill.

NORD, Christiane (1991) Text Analysis in Translation. Theory, Methodology and Didactic Application of a Model for Translation-oriented Text Analysis. Amsterdam, Atlanta. Rodopi.

OSOFISAN, Femi (2003) Il était une fois quatre voleurs, translated by Nicole Medjgbodo. Ibadan. Graduke Pubishers.

OSOFISAN, Femi (1980) Once upon four robbers. Ibadan. Mosuru Publishers.

SAMUEL, Beckett (1952) En Attendant Godot. Paris. Les Editions de Minuit.

SAMUEL, Beckett (1954) Waiting for Godot. New York. Grove Press

SELESKOVICH, Danica/Marianne LEDERER (2001) Interpréter pour Traduire. (4eth ed) Paris, Didier. Erudition.

STEINER, George (1975) After Compensation Babel: Aspects of Language and Translation. London and Oxford and New York. Oxford University Press, 396 
POVZETEK

\section{ANALIZA JEZIKOVNIH ZNAČILNOSTI FRANCOSKEGA PREVODA OSOFISANOVE IGRE ONCE UPON FOUR ROBBERS}

Analiza književnih besedil med drugim pogosto temelji na preučevanju jezikovnih značilnosti, ki so obenem seveda pomemben predmet prevodoslovnih raziskav. Osofisanova igra Once Upon Four Robbers je bila do danes deležna številnih analiz, ki pa niso ponudile odgovora na pereče vprašanje ustreznosti prevoda, katerega avtorji niso govorci jorubskega jezika, čeprav besedilo vsebuje elemente jorubske kulture. Dramsko delo Once Upon Four Robbers (1980) je v francoski jezik prevedla Nicole Medjigbodo (2003). S pomočjo opisnih in primerjalnih raziskovalnih metod smo analizirali naključno izbrane dele izvirnega in ciljnega besedila. Pri tem smo se opirali na interpretativno teorijo prevajanja, ki sta jo v 70-letih 20. stoletja predstavili D. Seleskovich in M. Lederer. Interpretativna teorija zagovarja trditev, da mora prevod na bralca narediti enak kognitivni, afektivni in estetski učinek kot izvirno besedilo. V pričujočem prispevku pokažemo, da je izvirne misli v afriških dramskih besedilih mogoče ohraniti oziroma jih prevesti s pomočjo ilustrativnih postopkov, $\mathrm{s}$ tem pa preprečiti, da bi se določene prvine v prevodu izgubile ali da ne bi bile ustrezno prevedene. V prispevku ugotavljamo, da dramsko besedilo Once Upon Four Robbers zaznamujejo številne značilnosti jorubske kulture, saj njegov avtor izhaja iz ljudstva Joruba. Prevod ustrezno posnema govorni tok (intonacijo, poudarke in jezikovne registre) izvirnega besedila, kar pomeni, da je prevedeno igro mogoče uprizoriti na enak način kot igro v izvirniku.

Ključne besede: značilnost, prevod, Once Upon Four Robbers, interpretativen, intonacija

\section{ABSTRACT}

From the onset, a linguistic feature is often one of the essential tools in analysing a literary work, and obviously it is sine qua non in translation studies. Many studies have been done on Osofisan's Once Upon Four Robbers but the issue of translations made by non-Yoruba native speaker where the material contains Yoruba cultural items is a contentious one. Once Upon Four Robbers (1980) was translated by Nicole Medjigbodo (2003). The study employs descriptive and comparative research methods in analysing random data taken from the source and target texts. We adopt Seleskovitch and Lederer's interpretative theory of translation (1970s). The theory postulates that the translation of a text should produce the same cognitive, affective and aesthetic effects on target readers as the original text does. The study, therefore, examines how to avoid translation loss or mistranslation $^{23}$ and thus ensure that indigenous thoughts in African drama texts can be retained or translated with the use of illustrative devices. The study therefore concludes that the text is rich in 
Yoruba cultural features as the playwright is a Yoruba man, and the speech flow (intonation, accentuation and register) in the translated version is in line with the source text. This shows that the translated play can be performed in the same way and as effectively as the original.

Keywords: Feature, translation, Once upon four robbers, interpretative, intonation 